\title{
Zmiany właściwości konsolidacyjnych, filtracyjnych i mikrostrukturalnych glin lodowcowych $w$ przebiegu badań konsolidacji z ciągłym wzrostem obciążenia
}

\author{
Piotr Stajszczak ${ }^{1}$, Paweł Dobak ${ }^{1}$, Katarzyna Gendek ${ }^{1}$
}

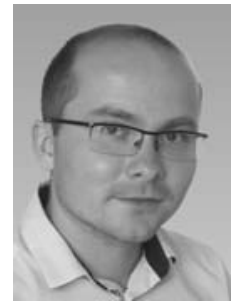

P. Stajszczak

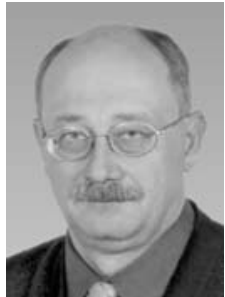

P. Dobak

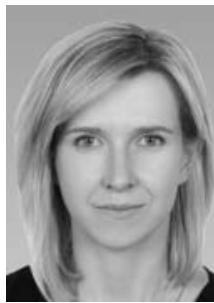

K. Gendek

Changes in the consolidation, seepage and microstructural properties of glacial tills estimated in continuous loading tests. Prz. Geol., 68: 843-852; doi: $10.7306 / 2020.36$

A b s tra $\mathrm{ct}$. The article presents results of CRL (Constant Rate of Loading) tests obtained for glacial till from the Warsaw region (Fort Stuzew). The analyses show that the significant factors affecting the course of the consolidation with continuous loading $(C L)$ of tested soils are related to the degree of water saturation of pore space, the state of soil structure, and the rate of loading. Values of filtration and consolidation parameters documented during CRL tests are dependent on the structural history and properties of soils. Before and after CRL tests, microstructure of till was studied by SEM methods. Changes in the pore space parameters in matrix microstructure, evaluated from CRL tests, are marked in different consolidation behaviours of tested natural and remould till.

Keywords: glacial till, consolidation with continuous loading, constant rate of loading test, permeability, microstructure

Ocena właściwości konsolidacyjno-filtracyjnych gruntów spoistych w powiązaniu z ich cechami mikrostrukturalnymi jest rozwojowym zagadnieniem zarówno badawczym, jak i praktycznym. Wyjaśnienia procesów konsolidacyjnych gruntów o różnej genezie należy poszukiwać między innymi w uwarunkowaniach strukturalnych. Określenie wpływu struktury gruntu na przebieg konsolidacji może się przyczynić do poprawy trafności prognoz osiadania, a także charakteryzowania właściwości izolacyjnych gruntów spoistych.

Proces konsolidacji gruntów spoistych w istotnym stopniu zależy od ich specyficznej, prawie znikomej przepuszczalności $\left(k<10^{-7} \mathrm{~m} / \mathrm{s}\right)$, związanej z prelinearną oraz quasi-linearną faza przepływu wody w przestrzeni porowej. Wiazże się to $\mathrm{z}$ rozpraszaniem nadwyżki ciśnienia porowego, powstającej na skutek zmian naprężenia w podłożu gruntowym (obciążenie zewnętrzne, wahania poziomu zwierciadła wód podziemnych) i warunkowanej litogenetycznymi, strukturalnymi oraz geologiczno-inżynierskimi właściwościami gruntu. Odniesienie do założeń teorii konsolidacji filtracyjnej Terzaghiego umożliwia porównywanie modelowych rozwiązań z doświadczalnymi charakterystykami oraz interpretowanie występujących rozbieżności m.in. zróżnicowanymi cechami strukturalnymi gruntów mineralnych, czego nie uwzględnia się zazwyczaj w założeniach modelowych. Szeroko prowadzone studia dowodzą, że zarówno przepuszczalność, jak i odkształcalność ośrodka gruntowego zależy od jego właściwości inherentnych (składu granulometrycznego i mineralnego) oraz przebytej historii geologicznej, wyrażonej warunkami sedymentacji, historią obciążenia, prekonsolidacją, obecnością lub brakiem cementacji szkieletu gruntowego (Szczepański, 2007; Bąkowska i in., 2016; Zawrzykraj i in., 2017). Warunki sedymentacji oraz procesy postsedymentacyjne kształtują mikrostruktury gruntów, które wpływają na geologiczno-inżynierskie właściwości podłoża budowlanego (Sergeyev i in., 1980; Trzciński, 1995; Zhang i in., 2016).
Laboratoryjną ocenę filtracyjno-konsolidacyjnych cech gruntu spoistego przeprowadza się najczęściej w przebiegu jednoosiowych badań ściśliwości. Tradycyjne badania edometryczne typu IL (incremental loading), prowadzone najczęściej bez pomiaru ciśnienia porowego, pozwalają jedynie pośrednio szacować aspekty filtracyjne (Duncan, 1993). Badania konsolidacji pod stałym obciążeniem z równoczesnym pomiarem ciśnienia porowego wiążą się z zachowaniem różnych wymagań laboratoryjnych $\mathrm{w}$ trakcie dhugotrwałych obserwacji, m.in. przyjmowaniem czasu trwania poszczególnych etapów obciążenia, schematem zwiększania naprężenia całkowitego, dokładnością prowadzonych odczytów, wymiarami badanej próbki, wymaganiami sprzętowymi itp. (Head, 1986; PN-88/B-04481; PN-EN ISO 17892-5). Umożliwiają one jednak doświadczalną ocenę relacji pomiędzy rozpraszaniem ciśnienia porowego a odkształceniem osiowym i wyznaczanie parametrów filtracyjno-konsolidacyjnych w nawiązaniu do różnych ujęć teoretycznych (Pająk, Dobak, 2008; Dobak, Gaszyński, 2015).

Coraz szerzej w analizach właściwości gruntów są stosowane badania konsolidometryczne prowadzone $\mathrm{w}$ warunkach stałego wzrostu obciążenia (CRL) z ciągłym monitoringiem odkształcenia osiowego i ciśnienia porowego mierzonego przy dolnej, nieprzepuszczalnej podstawie próbki badanego gruntu (Aboshi i in., 1970; Soumaya, Kempfert, 2010; Kowalczyk i in., 2013; Stajszczak, 2018, 2019). Taki schemat badawczy umożliwia lepszą ocenę czynników filtracyjnych, ale wymaga odniesienia do rozwiązań definiujących konsolidację typu CL (continuous loading; Dobak, 1999, 2008). Przebieg konsolidacji w tych badaniach jest warunkowany m.in. opcjonalną prędkością obciążania oraz charakterystyką geologiczno-inżynierską gruntu - składem granulometrycznym, mineralnym, porowatością, stopniem wilgotności, przepuszczalnością oraz ściśliwością (Dobak, 2003; Soumaya, Kempfert, 2010;

\footnotetext{
${ }^{1}$ Wydział Geologii, Uniwersytet Warszawski, ul. Żwirki i Wigury 93, 02-089 Warszawa; piotrek25104@wp.pl; p.dobak@uw.edu.pl; k.gendek@student.uw.edu.pl
} 
Stajszczak, 2018). Czynniki te są powiązane z charakterystyką mikrostruktury gruntu spoistego (obecnością lub brakiem uprzywilejowanych dróg filtracji, sposobem ułożenia poszczególnych cząstek i ziaren, orientacją porów itp.).

Przebieg konsolidacji CL z uwzględnieniem zachodzących zmian mikrostruktury gruntu spoistego przedstawiono w niniejszym artykule na przykładzie badań glin zlodowacenia odry, które powszechnie występują na terenie Warszawy. Grunty glacjalne powstałe w wyniku bezpośredniej depozycji z lądolodu należą na obszarze kraju do jednych z najbardziej pospolitych osadów czwartorzędowych (Kaczyński, 2017).

\section{METODYKA BADAŃ}

Celem badań opisanych w niniejszym artykule jest ocena:

$\square$ wpływu czynników strukturalnych na charakterystykę przebiegu konsolidacji CL w gruntach o naturalnej strukturze i w specjalnie preparowanych pastach gruntowych;

$\square$ zgodności doświadczalnych charakterystyk procesu $\mathrm{z}$ istniejącymi rozwiązaniami teoretycznymi na tle uwarunkowań nasycenia porów wodą: $\mathrm{Sr}<1$ lub $\sim 1$;

$\square$ zmian ciśnienia porowego i odkształcenia w nawiązaniu do stosowanych prędkości obciążenia;

$\square$ zróżnicowania przebiegów badań CRL na tle jakościowych oraz ilościowych zmian mikrostrukturalnych w glinach lodowcowych.

Grunty przeznaczone do badań konsolidacyjnych i mikrostrukturalnych wycinano w postaci monolitów o nienaruszonej strukturze ze ścian głębokich wykopów fundamentowych (ok. 8-metrowych) osiedla mieszkaniowego Fort Służew na warszawskim Ursynowie. W wykopach tych zaobserwowano zróżnicowanie litologiczne charakterystyczne dla utworów zwałowych, co makroskopowo pozwala je określać jako grunty o cechach glin zwięzłych i iłów z domieszkami pylastymi, występujące $\mathrm{w}$ stanie twardoplastycznym lub półzwartym. Obserwacje te zostały potwierdzone przez wyniki laboratoryjnych badań składu granulometrycznego i parametrów fizycznych.

Skład mineralny oznaczono metodą derywatograficzną oraz dyfraktometryczną. Analiza derywatograficzna (termiczna) została wykonana w aparacie Q600 firmy TA, a interpretację otrzymanych wyników przeprowadzono wg zaleceń metodycznych Kościówko i Wyrwickiego (1996).

W celu uwzględnienia wpływu czynników teksturalno-strukturalnych na uzyskiwane charakterystyki konsolidacyjne przeprowadzano badania CL oraz mikrostrukturalne zarówno próbek o nienaruszonej strukturze, jak i past gruntowych. Pasty gruntowe przygotowywano według procedury opisanej w pra- cach Kowalczyka i in. (2013) oraz Stajszczaka (2019). Wstępna konsolidacja past gruntowych na specjalnym stanowisku była prowadzona pod stałym obciążeniem przez 5 tygodni. W tym czasie stan gruntu zmienił się z płynnego $\mathrm{w}$ miękkoplastyczny.

Właściwe badania konsolidacyjne wykonywano w komorze Bardena-Rowe'a. W programie badań zastosowano różne prędkości obciążania (CRL-constant rate of loading), ale stałe $\mathrm{w}$ danym teście:

12,$5 ; 25 ; 50$ oraz $100 \mathrm{kPa} / \mathrm{h}$ w badaniach past gruntowych;

$\square 50$ oraz $100 \mathrm{kPa} / \mathrm{h}$ w badaniach próbek o naturalnej, nienaruszonej strukturze (NNS).

Badania prowadzono do osiągnięcia maksymalnej wartości naprężenia całkowitego $\sigma=2000 \mathrm{kPa}$. Tak duży zakres nie jest stosowany $\mathrm{w}$ najczęściej rozpatrywanych praktycznych problemach, lecz umożliwia metodyczną ocenę wpływu różnych prędkości obciążania na osiaganie ustalonej fazy badania CL i określenie zaleceń doboru optymalnej prędkości prowadzenia standardowych badań.

Badania CRL próbek NNS przeprowadzono zarówno z zastosowaniem, jak i pominięciem procedury nasycania metodą ciśnienia wstecznego (back pressure). Dzięki temu możliwe było określenie wpływu stopnia nasycenia gruntu spoistego na przebieg i parametry konsolidacji CL w warunkach stale wzrastającego obciążenia (tab. 1). Procedurę saturacji prowadzano w warunkach ciśnienia wstecznego rzędu 420-460 kPa.

Zautomatyzowane pomiary wartości naprężenia całkowitego $\sigma$, drogi drenażu $H$ oraz ciśnienia porowego $u_{b}$ umożliwiają wyznaczenie specjalnie wyprowadzonych parametrów konsolidacji, dostosowanych do warunków badania CRL (tab. 1).
Tab. 1. Parametry definiujące przebieg konsolidacji CL. Objaśnienia symboli: $H$-droga drenażu $[\mathrm{m}], \gamma_{w}$ - ciężar objętościowy wody $\left[\mathrm{kN} / \mathrm{m}^{3}\right], u_{b}$ - ciśnienie porowe $[\mathrm{kPa}], \sigma$ - naprężenie całkowite $[\mathrm{kPa}], \sigma^{\prime}$ - naprężenie efektywne $[\mathrm{kPa}]$

Table 1. Parameters defining the course of CL consolidation. Explanations: $H$ - length of drainage path $[\mathrm{m}], \gamma_{w}-$ unit weight of water $\left[\mathrm{kN} / \mathrm{m}^{3}\right], u_{b}$ - pore water pressure $[\mathrm{kPa}], \sigma-$ total stress $[\mathrm{kPa}], \sigma^{\prime}-$ effective stress $[\mathrm{kPa}]$

\begin{tabular}{|c|c|c|}
\hline $\begin{array}{l}\text { Parametr } \\
\text { Parameter }\end{array}$ & $\begin{array}{l}\text { Wzór } \\
\text { Formula }\end{array}$ & $\begin{array}{c}\text { Jednostka } \\
\text { Unit }\end{array}$ \\
\hline $\begin{array}{l}\text { Naprężenie efektywne } \\
\text { Effective stress }\end{array}$ & $\sigma^{\prime}=\sigma-\frac{2}{3} u_{b}$ & $\mathrm{kPa}$ \\
\hline $\begin{array}{l}\text { Moduł ściśliwości } \\
\text { Modulus of compressibility }\end{array}$ & $M_{o}=\frac{\Delta \sigma^{\prime} \cdot H_{i-1}}{H_{i-1}-H_{i}}$ & $\mathrm{kPa}$ \\
\hline $\begin{array}{l}\text { Parametr ciśnienia wody w porach } \\
\text { Parameter of pore water pressure }\end{array}$ & $C_{C L}=\frac{u_{b}}{\sigma}$ & {$[-]$} \\
\hline \multirow{4}{*}{$\begin{array}{l}\text { Współczynniki korekcyjne wg Janbu i in. (1981) } \\
\text { Correction coefficients according to Janbu et al. (1981) }\end{array}$} & $\lambda=\frac{\Delta u_{b}}{\Delta \sigma}$ & {$[-]$} \\
\hline & $a_{j}=\operatorname{arcosh}\left(\frac{1}{1-\lambda}\right)$ & {$[-]$} \\
\hline & $\alpha_{c v}=\frac{2\left[\cosh \left(a_{j}\right)-1\right]}{\left(a_{j}\right)^{2} \cosh \left(a_{j}\right)}$ & {$[-]$} \\
\hline & $\alpha_{k}=\frac{2\left[\cosh \left(a_{j}\right)-1\right]}{\left(a_{j}\right) \sinh \left(a_{j}\right)}$ & {$[-]$} \\
\hline $\begin{array}{l}\text { Współczynnik konsolidacji } \\
\text { Coefficient of consolidation }\end{array}$ & $c_{v}=\alpha_{c v} \cdot \frac{\Delta \sigma \cdot \mathrm{H}^{2}}{\Delta t \cdot 2 \cdot u_{b}}$ & $\mathrm{~m}^{2} / \mathrm{s}$ \\
\hline $\begin{array}{l}\text { Współczynnik filtracji } \\
\text { Coefficient of permeability }\end{array}$ & $k=\alpha_{k} \cdot \frac{c_{v} \cdot \gamma_{w}}{M_{0}}$ & $\mathrm{~m} / \mathrm{s}$ \\
\hline
\end{tabular}


Współczynniki konsolidacji $c_{v}$ oraz filtracji $k$ wyznaczano z uwzględnieniem poprawek $\alpha_{c v}, \alpha_{k}$, zaproponowanych przez Janbu i in. (1981), umożliwiających korektę wartości tych parametrów $\mathrm{w}$ fazie wzrastania ciśnienia porowego, która poprzedza jego modelową stabilizację.

Badania SEM mikrostruktur glin lodowcowych z rejonu Fortu Służew przeprowadzono w Środowiskowym Laboratorium Niskotemperaturowej Skaningowej Mikroskopii Elektronowej Cryo-SEM na Wydziale Geologii Uniwersytetu Warszawskiego z zastosowaniem mikroskopu skaningowego Jeol JSM 6380 LA. Próbki do badań SEM pobierano przed rozpoczęciem badania $\mathrm{CRL}$, jak również po jego zakończeniu. Do ilościowego scharakteryzowania zróżnicowania wybranych morfometrycznych elementów strukturalnych wykorzystano specjalistyczne oprogramowanie STIMAN.

\section{WYNIKI BADAŃ}

Wyniki badań laboratoryjnych umożliwiły scharakteryzowanie właściwości fizycznych, filtracyjno-konsolidacyjnych oraz mikrostrukturalnych analizowanych glin lodowcowych o naturalnej strukturze, a także past gruntowych o takim samym składzie granulometryczno-mineralnym, lecz pozbawionych postsedymentacyjnych więzi strukturalnych.

\section{Właściwości fizyczne}

Pod względem granulometrycznym badane gliny lodowcowe zalicza się do grupy gruntów bardzo spoistych (tab. 2), tj. iłów (PN-86/B-02480; PN_EN ISO 14688-1,2). Są one jednorodne, ciemnobrązowe, mało wilgotne i w warunkach naturalnych występują $\mathrm{w}$ stanie na pograniczu półzwartego i twardoplastycznego. Makroskopowo ich struktura została oceniona jako jednorodna, bez wyraźnych smug oraz przewarstwień.

Przeprowadzona analiza składu mineralnego wykazała, że w badanej próbce gliny lodowcowej minerały ilaste stanowiły $31,4 \%$ (w tym beidelit $17,6 \%$, illit $10,6 \%$ oraz kaolinit $3,2 \%$ ). Stwierdzono też $5,6 \%$ węglanów (kalcytu oraz dolomitu), natomiast zawartość minerałów nieaktywnych termicznie (kwarc, skalenie, minerały ciężkie) oszacowano na 63,0\%. Obecność asymetrycznej endodermy z maksimum w temperaturze $573^{\circ} \mathrm{C}$ wskazuje (Kościówko, Wyrwicki, 1996), że zawartość kwarcu w badanej glinie lodowcowej wynosi co najmniej $40 \%$ lub więcej. Taki skład mineralny jest typowy i reprezentatywny dla regionalnych charakterystyk rozpatrywanych glin lodowcowych (Trzciński, 1995; Bąkowska i in., 2016).

Wskaźnik plastyczności $I_{p}$ badanych utworów kształtuje się $w$ przedziale od 25,0 do $28,5 \%$, co sytuuje je w grupie gruntów zwięzło spoistych, a nie w bardzo spoistych, jakby to wynikało z zawartości frakcji iłowej (PN-86/B-02480). Są to jednak grunty typu zwałowego, co powoduje, że ich spoistość jest obniżona w stosunku do osadów zastoiskowych przez losowe rozłożenie grubszych frakcji. Skład mineralny i granulometryczny rzutują także na ich aktywność (A: 0,63-0,89), mieszczącą się w klasie gruntów mało- oraz normalnie aktywnych (Myślińska, 2001). Wynika stąd znikomy wpływ ewentualnych właściwości ekspansywnych na ściśliwość i konsolidację.
Zmienność wartości podstawowych parametrów fizycznych gruntów o nienaruszonej strukturze oraz past, przedstawioną w tab. 2, można traktować jako tło sygnalizujące zróżnicowanie ich cech strukturalnych. Badane gliny w warunkach naturalnych charakteryzują się gęstością objętościową ok. 10-20\% większą od gęstości próbek przygotowanych z past gruntowych. Porowatość gruntów o nienaruszonej strukturze była o ok $50-70 \%$ mniejsza od porowatości past gruntowych. Przy gęstości właściwej szkieletu mineralnego ok. $2,66-2,67 \mathrm{Mg} / \mathrm{m}^{3}$, pozbawienie gruntu naturalnej struktury skutkowało ponad dwukrotnym zwiększeniem wartości wskaźnika porowatości past gruntowych, co znalazło odpowiednie odzwierciedlenie w ich ściśliwości.

Różnice między wilgotnością naturalną glin i past rzędu $18-21 \%$ skutkuja znaczącymi zmianami stopnia plastyczności, natomiast nie rzutują na istotne zmiany stopnia wilgotności. Parametr ten, wskazujący na wypełnienie przestrzeni porowej woda, w przypadku past ma wartość $\mathrm{Sr}=1$, natomiast $\mathrm{w}$ twardoplastycznych lub półzwartych glinach w stanie naturalnym wynosi od 0,97 do 1 . Pozwala to w przypadku tych ostatnich traktować część próbek naturalnych glin jako układ quasi-dwufazowy, odpowiadający w przybliżeniu założeniom teorii konsolidacji Terzaghiego.

\section{Przebieg konsolidacji CL}

Parametrem wyznaczanym bezpośrednio do oceny filtracyjno-konsolidacyjnych właściwości gruntu jest ciśnienie porowe $u_{b}$. Zmiany jego wartości dokumentują udział fazy ciekłej gruntu w przenoszeniu zadawanego obciążenia

Tab. 2. Parametry fizyczne gliny lodowcowej z terenu osiedla Fort Służew w Warszawie oznaczone przed rozpoczęciem badań CRL

Table 2. Physical parameters of glacial till from the area of Fort Służew in Warsaw obtained before CRL tests

\begin{tabular}{|c|c|c|}
\hline $\begin{array}{l}\text { Parametr } \\
\text { Parameter }\end{array}$ & $\begin{array}{c}\text { Próbki NNS } \\
\text { Undisturbed sample }\end{array}$ & $\begin{array}{c}\text { Pasty gruntowe } \\
\text { Soil paste }\end{array}$ \\
\hline $\begin{array}{l}\text { Wilgotność } \\
\text { Moisture content } w[\%]\end{array}$ & $15,3-18,9$ & $36,8-39,7$ \\
\hline $\begin{array}{l}\text { Granica plastyczności } \\
\text { Plastic limit } w_{p}[\%]\end{array}$ & \multicolumn{2}{|c|}{$15,1-18,0$} \\
\hline $\begin{array}{l}\text { Granica płynności } \\
\text { Liquid limit } w_{L}[\%]\end{array}$ & \multicolumn{2}{|c|}{$40,3-46,2$} \\
\hline $\begin{array}{l}\text { Stopień plastyczności } \\
\text { Liquidity index } I_{L}[-]\end{array}$ & $-0,06-0,11$ & $0,74-0,85$ \\
\hline $\begin{array}{l}\text { Gęstość właściwa } \\
\text { Density } \rho_{s}\left[\mathrm{Mg} / \mathrm{m}^{3}\right]\end{array}$ & \multicolumn{2}{|l|}{2,66} \\
\hline $\begin{array}{l}\text { Gęstość objętościowa } \\
\text { Bulk density } \rho\left[\mathrm{Mg} / \mathrm{m}^{3}\right]\end{array}$ & $2,10-2,14$ & $1,83-1,86$ \\
\hline $\begin{array}{l}\text { Porowatość } \\
\text { Porosity } n[-]\end{array}$ & $0,30-0,33$ & $0,49-0,51$ \\
\hline $\begin{array}{l}\text { Wskaźnik porowatości } \\
\text { Void ratio } e[-]\end{array}$ & $0,43-0,50$ & $0,96-1,04$ \\
\hline $\begin{array}{l}\text { Stopień wilgotności } \\
\text { Degree of saturation } S_{r}[-]\end{array}$ & $0,97-1,00$ & 1,00 \\
\hline $\begin{array}{l}\text { Frakcja iłowa } \\
\text { Clay fraction } f_{i}[\%]\end{array}$ & \multicolumn{2}{|c|}{$31-44$} \\
\hline $\begin{array}{l}\text { Frakcja pyłowa } \\
\text { Silt fraction } f_{\pi}[\%]\end{array}$ & \multicolumn{2}{|c|}{$22-38$} \\
\hline $\begin{array}{l}\text { Frakcja piaskowa } \\
\text { Sand fraction } f_{p}[\%]\end{array}$ & \multicolumn{2}{|c|}{$27-39$} \\
\hline
\end{tabular}


oraz warunki filtracji wymuszanej w trakcie procesu konsolidacji.

W zrealizowanym programie badań glin zlodowacenia odry maksymalne wartości ciśnienia porowego uzyskano w próbkach o strukturze naturalnej. Najwyższe ciśnienia panowały w gruntach poddanych uprzednio nasycaniu techniką back pressure, a o około połowę niższe, ale też znaczące, w próbkach o naturalnej strukturze (NNS) i wilgotności. Najmniejsze przyrosty wartości ciśnienia porowego występowały w pastach, gdzie pozbawienie materiału gruntowego naturalnej struktury skutkowało także odmiennym kształtem krzywych przedstawiających zależność $u_{b}-\sigma$ (ryc. 1).

W próbkach o naturalnej strukturze ciśnienie porowe zwiększało się sukcesywnie wraz z rosnącym naprężeniem całkowitym. Natomiast w pastach gruntowych po osiagnięciu maksymalnej wartości $\left(u_{b \max }\right)$ następowało niewielkie zmniejszenie ciśnienia porowego $\left(u_{b}\right)$, a następnie jego quasi-stabilizacja. Te anomalie w stosunku do charakterystyk modelowych (Dobak, 1999, 2008; Stajszczak, 2018) mogą świadczyć o przebudowie mało stabilnej struktury past na skutek rozpraszania najwyższych wartości wygenerowanej nadwyżki ciśnienia porowego.

Istotnym wskaźnikiem oceny typu konsolidacji w badaniach CL jest przebieg zmian bezwymiarowego parametru ciśnienia wody w porach $C_{C L}=u_{b} / \sigma$, analizowany w funkcji naprężenia (ryc. 2) lub czasu. Porównawcza ocena uzyskanych charakterystyk obejmuje warunki osiagania najwyższych wartości $C_{C L}$, a następnie przebieg zmian tego parametru w dalszym toku badania.
Najwyższe wartości $C_{C L m a x} \sim 1$, występujące w chwili przyłożenia obciążenia, odnotowano $\mathrm{w}$ badaniach past. Opóźnione osiaganie wartości $C_{C L \max }$ i znacząco niższe ich wartości obserwuje się w badaniach próbek gruntu o naturalnej strukturze i wilgotności. Natomiast porównywalne podwyższenie wartości $C_{C L}$ osiagano po nasyceniu gruntu wodą techniką back-pressure. Modelowy przebieg zmniejszania się wartości $C_{C L}$ w funkcji $\sigma$ występował właściwie tylko $\mathrm{w}$ pastach, natomiast $\mathrm{w}$ badaniach próbek o naturalnej strukturze obserwowano liczne anomalie przebiegu zmian tego parametru (ryc. 2) w stosunku do teoretycznych oczekiwań.

Współczynnik konsolidacji $c_{v}$ zarówno past gruntowych, jak i próbek o naturalnej strukturze wykazuje najwyższe i niemiarodajne wartości na początku badania, co wynika z opóźnionej mobilizacji ciśnienia porowego (ryc. 1). Wraz z postępującym wzrostem naprężenia całkowitego i ciśnienia porowego obliczany współczynnik konsolidacji $c_{v}$ sukcesywnie zmniejsza się (ryc. 3), zmierzając do quasi-ustalonych, miarodajnych wartości.

W badaniach próbek glin lodowcowych wartości oceniane jako miarodajne kształtują się w przedziale od 2 do $8 \cdot 10^{-9} \mathrm{~m}^{2} / \mathrm{s}$ (ryc. 3A), natomiast w pastach uzyskano wartości odpowiednio wyższe (od 0,8 do 1,2$) \cdot 10^{-8} \mathrm{~m}^{2} / \mathrm{s}$, co może wynikać z lepszych warunków rozpraszania ciśnienia porowego w ich mniej stabilnym układzie strukturalnym (ryc. 3B). Warto zauważyć, że niepełne nasycenie wodą gruntów w stanie naturalnym, pomimo zastosowania dużej prędkości obciążenia, nie pozwala niekiedy wygenerować wystarczającego ciśnienia porowego i obliczane

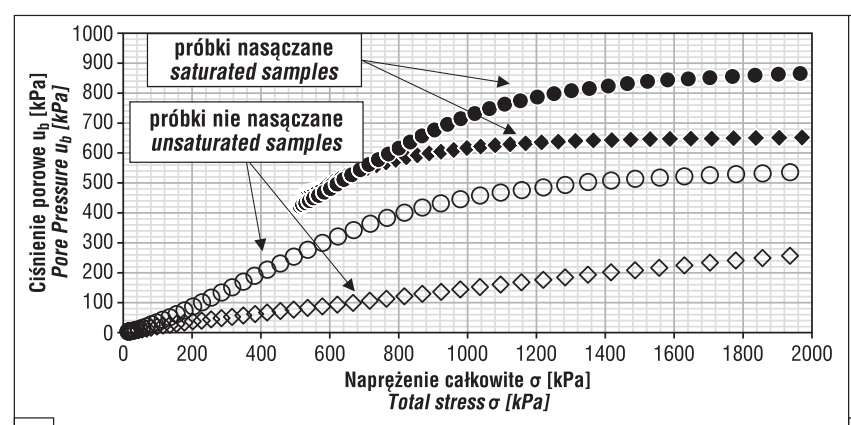

A

Ryc. 1. Ciśnienie porowe uzyskane w trakcie badań CRL glin lodowcowych występujących w rejonie osiedla Fort Służew w Warszawie: A - próbek NNS; B - past gruntowych sporządzonych z tych glin. Objaśnienia: $\mathbf{N}$ - próbka niesaturowana, $\mathbf{S}$ - próbka saturowana, $\mathbf{P}$ - pasta gruntowa Fig. 1. The pore pressure values obtained during CRL tests of glacial tills occurring in the area of Fort Służew (Warsaw): A-undisturbed samples; B ground pastes made from the glacial tills. Explanations: $\mathbf{N}$ - unsaturated sample, $\mathbf{S}$ - saturated sample, $\mathbf{P}-$ soil paste
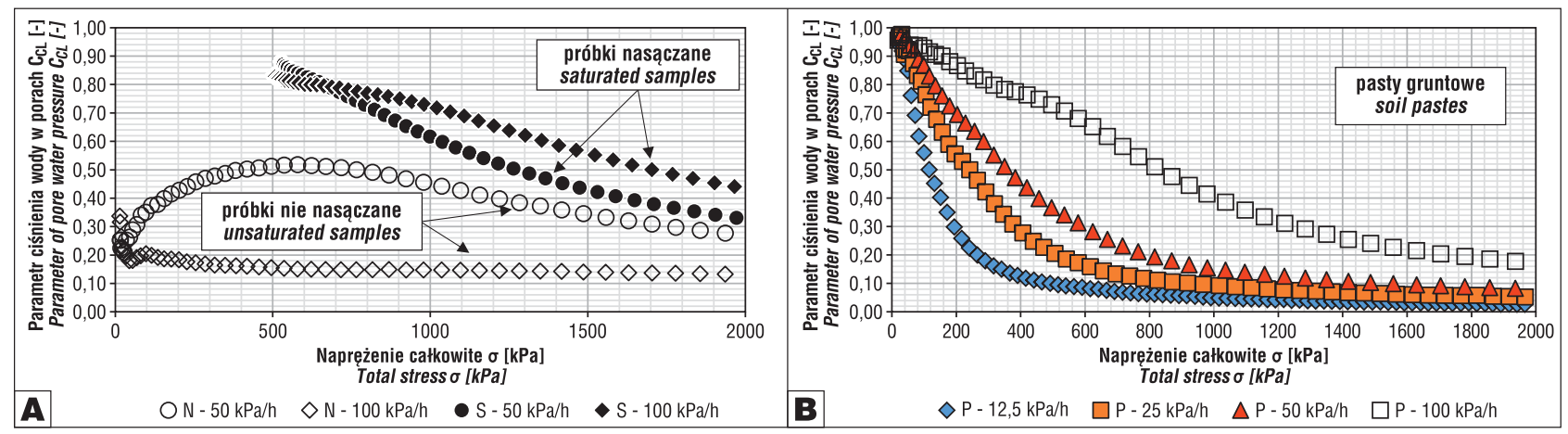

Ryc. 2. Ciśnienie wody w porach uzyskane w trakcie badań CRL próbek NNS (A) oraz past gruntowych (B) sporządzonych z glin lodowcowych występujących w rejonie Fortu Służew w Warszawie. Objaśnienia: $\mathbf{N}$ - próbka niesaturowana, $\mathbf{S}$ - próbka saturowana, $\mathbf{P}$ - pasta gruntowa

Fig. 2. The values of water pressure parameter obtained during CRL tests of undisturbed samples $(\mathbf{A})$ and ground pastes $(\mathbf{B})$ made from glacial tills occurring in the area of Fort Służew (Warsaw). Explanations: $\mathbf{N}$ - unsaturated sample, $\mathbf{S}$ - saturated sample, $\mathbf{P}$ - soil paste 
wartości $c_{v}$ mogą być znacząco zawyżone i niemiarodajne (np. badanie $\mathrm{N}-100 \mathrm{kPa} / \mathrm{h}$; ryc. $3 \mathrm{~A}$ ).

Zmiany wartości współczynnika filtracji $k$ dokumentują liniowy trend zmniejszania przepuszczalności ośrodka gruntowego w funkcji zmniejszania wskaźnika porowatości gruntu $e$ (ryc. 4). W próbkach o naturalnej strukturze zmiany te są mniejsze i kształtowały się w przedziałach: od $5,1 \times 10^{-9}$ do $2,6 \times 10^{-12} \mathrm{~m} / \mathrm{s}$ w badaniach próbek o naturalnej wilgotności oraz od 9,2 $\times 10^{-11}$ do $1,1 \times 10^{-12} \mathrm{~m} / \mathrm{s} \mathrm{w}$ próbkach poddanych saturacji. W pastach gruntowych zmiany te są kilkakrotnie większe i wyznaczał je przedział wartości $k$ od $3,2 \times 10^{-9}$ do $3,4 \times 10^{-12} \mathrm{~m} / \mathrm{s}$.

\section{Mikrostruktura}

Wyniki badań przeprowadzonych pod mikroskopem skaningowym wskazują, że gliny lodowcowe zlodowace- nia odry z rejonu osiedla Fort Służew w Warszawie w stanie naturalnym maja cechy mikrostruktury matrycowej, dla której charakterystyczne jest bezładne występowanie ziaren frakcji pyłowej oraz piaskowej w dominującej matrycy ilastej. Opis ten nawiązuje do szeroko stosowanej klasyfikacji, przedstawianej m.in. w pracach Sergeyeva i in. (1980) oraz Sokolova (1990). Matrycę ilastą badanych próbek tworzą mikroagregaty cząstek ilastych, które na uzyskanych obrazach SEM nie wykazują wyraźnej orientacji przestrzennej. Przeważającym typem kontaktów pomiędzy poszczególnymi minerałami ilastymi są kontakty typu płaszczyzna-płaszczyzna $F-F$ (face-face). Niemniej w obrazach próbek o naturalnej strukturze pory występujące pomiędzy mikroagregatami były najczęściej wydłużone, przeważnie w kierunku pionowym (ryc. 5A).

Porównanie obrazów mikrostrukturalnych past gruntowych oraz próbek NNS przed ich obciążeniem w konsoli-
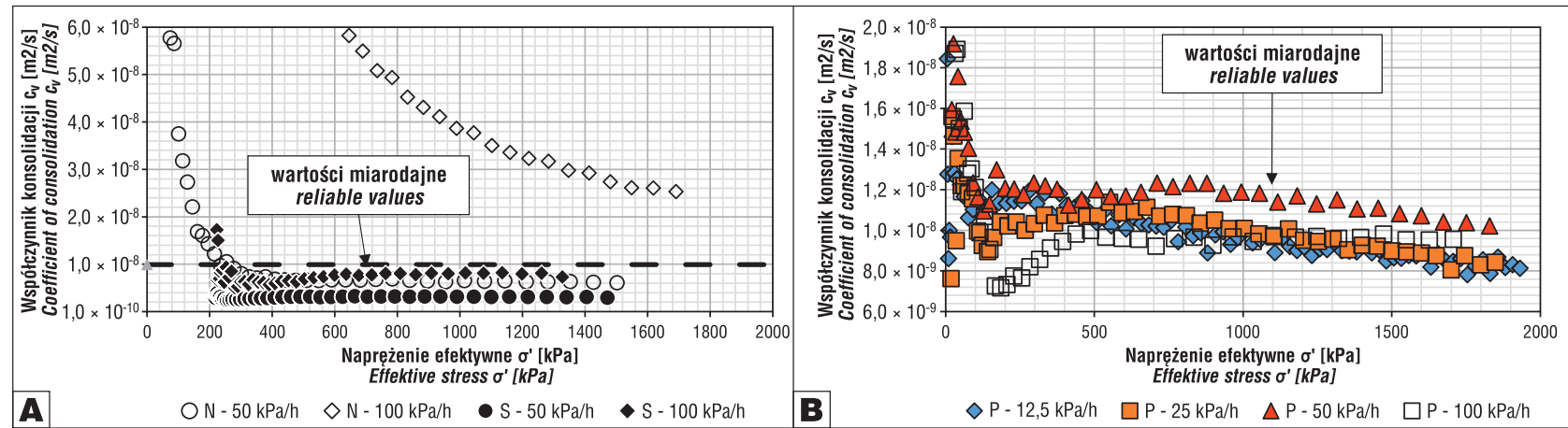

Ryc. 3. Wartości współczynnika konsolidacji uzyskane w trakcie badań CRL próbek NNS (A) oraz past gruntowych (B) sporządzonych z glin lodowcowych występujących w rejonie Fortu Służew w Warszawie. Objaśnienia: $\mathbf{N}$ - próbka niesaturowana, $\mathbf{S}$ - próbka saturowana, $\mathbf{P}$ - pasta gruntowa

Fig. 3. The consolidation coefficient values obtained during CRL tests of undisturbed samples (A) and ground pastes (B) made from glacial tills occurring in the area of Fort Służew in Warsaw. Explanations: $\mathbf{N}$ - unsaturated sample, $\mathbf{S}$ - saturated sample, $\mathbf{P}$ - soil paste

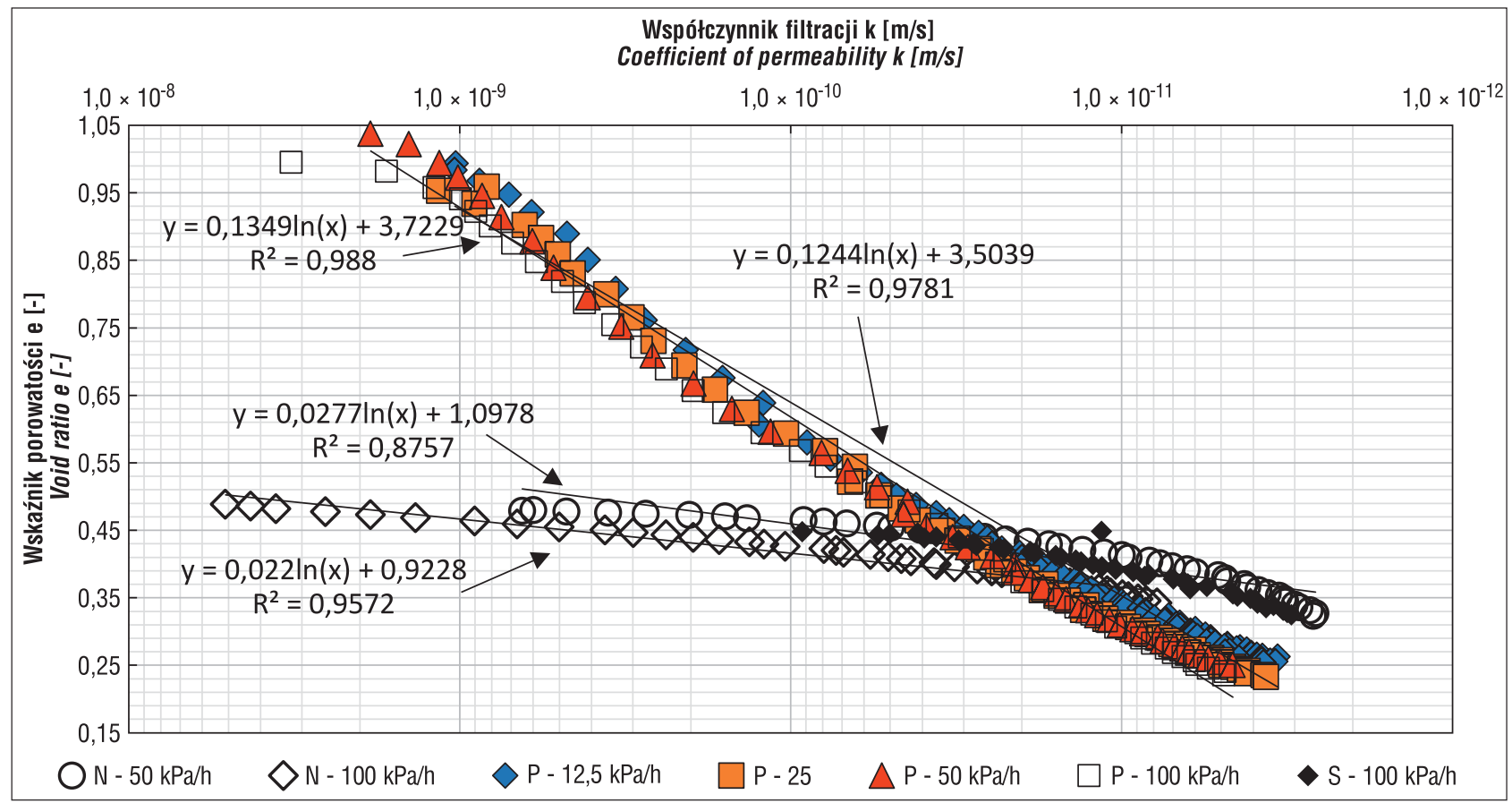

Ryc. 4. Wartości współczynnika filtracji uzyskane w trakcie badań CRL próbek NNS oraz past gruntowych sporządzonych z glin lodowcowych występujących w rejonie Fortu Służew w Warszawie. Objaśnienia: $\mathbf{N}$ - próbka niesaturowana, $\mathbf{S}$ - próbka saturowana, $\mathbf{P}$ - pasta gruntowa

Fig. 4. The permeability coefficient values obtained during CRL tests of undisturbed samples and ground pastes made from glacial tills occurring in the area of Fort Służew in Warsaw. Explanations: $\mathbf{N}$ - unsaturated sample, $\mathbf{S}$ - saturated sample, $\mathbf{P}$ - soil paste 
dometrze wskazuje, że matryca ilasta past gruntowych, w przeciwieństwie do próbek o zachowanej naturalnej strukturze, charakteryzuje się luźnym upakowaniem ziaren i cząstek (ryc. 5B). Mikroagregaty minerałów ilastych w pastach mają kształt zbliżony do izometrycznego, a dominującym typem kontaktów pomiędzy poszczególnymi cząstkami są kontakty typu krawędź-krawędź $E-E$ (edge-edge). Pory są liczniejsze niż w strukturze próbek NNS, a ich kształt jest izometryczny (ryc. 5B).

Po przeprowadzeniu badań CRL mikrostruktury próbek glin lodowcowych oraz past gruntowych wykazuja lepsze upakowanie. Struktura wszystkich badanych próbek po obciążeniu została uznana za matrycowo-turbulentną. Kontakty między poszczególnymi minerałami ilastymi są typu płaszczyzna-płaszczyzna $F-F$. Pory przyjmują kształt wydłużony o orientacji zbliżonej do poziomej (ryc. 6).

Przedstawione klasyfikacje uzupełniają ilościowe charakterystyki parametrów przestrzeni porowej. Pokazuja one, że przed obciążeniem i konsolidacją wyjściowe wartości porowatości $n$, średniej średnicy porów $D_{a v}$ oraz całkowitego obwodu porów $P_{t}$ próbek o naturalnej strukturze są około 2 razy mniejsze aniżeli w przypadku układu strukturalnego past gruntowych. Zakresy zmniejszenia wartości analizowanych parametrów morfometrycznych po przeprowadzeniu badań w konsolidometrze Bardena-Rowe'a przedstawiono w tab. 3.

Parametrem geometrycznym dobrze ilustrującym różnice oraz zmiany przestrzenne zaobserwowane $\mathrm{w}$ materiale badawczym, wynikające z obciążania i konsolidacji próbek, jest wskaźnik anizotropii mikrostruktury $K_{\alpha}$. Analizując wartości tego parametru, oznaczone przed i po przeprowadzeniu badań konsolidometrycznych, odnotowano zwiększenie kierunkowości orientacji mikrostruktur zarówno w glinach lodowcowych o naturalnej strukturze, jak i w pastach. Średnio wartość $K_{\alpha}$ po obciążeniu past wzrosła z 21,8\% do 33,9\%, a w próbkach o niezniszczonej naturalnej strukturze z 14,6 do 30,0\%.

\section{INTERPRETACJA WYNIKÓW BADAŃ}

Przeprowadzone badania CRL glin zlodowacenia odry oraz sporządzonych z nich past dokumentują wpływ różnych cech materiału gruntowego, takich jak mikrostruktura, nasycenie porów wodą i właściwości inherentne, oraz stosowanych prędkości obciążania na przebieg odkształcania i konsolidacji (Sinha, Bhargava, 1991). Reakcja dwu- lub
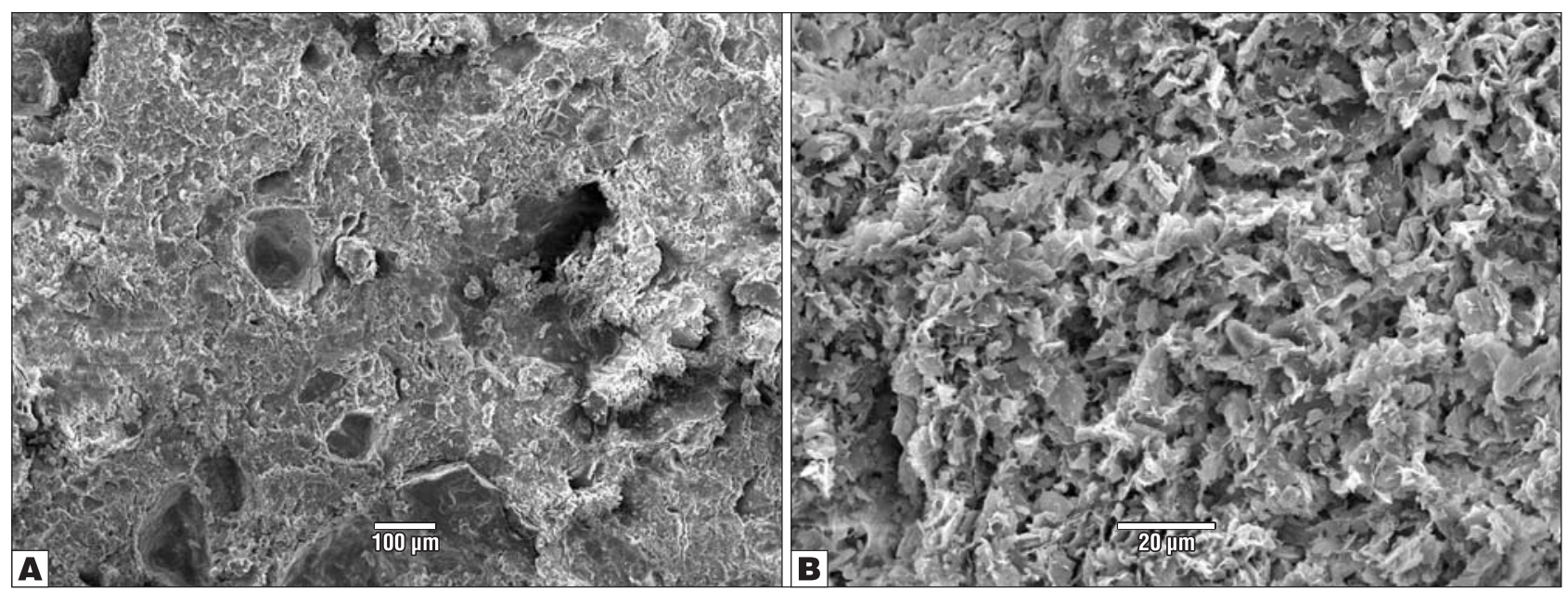

Ryc. 5. Mikrostruktura matrycowa gliny lodowcowej z rejonu Fortu Służew w Warszawie: A - próbka o nienaruszonej strukturze; B - pasta gruntowa

Fig. 5. Matrix microstructure of glacial till from the area of Fort Służew in Warsaw: A - undisturbed sample; $\mathbf{B}$ - soil paste
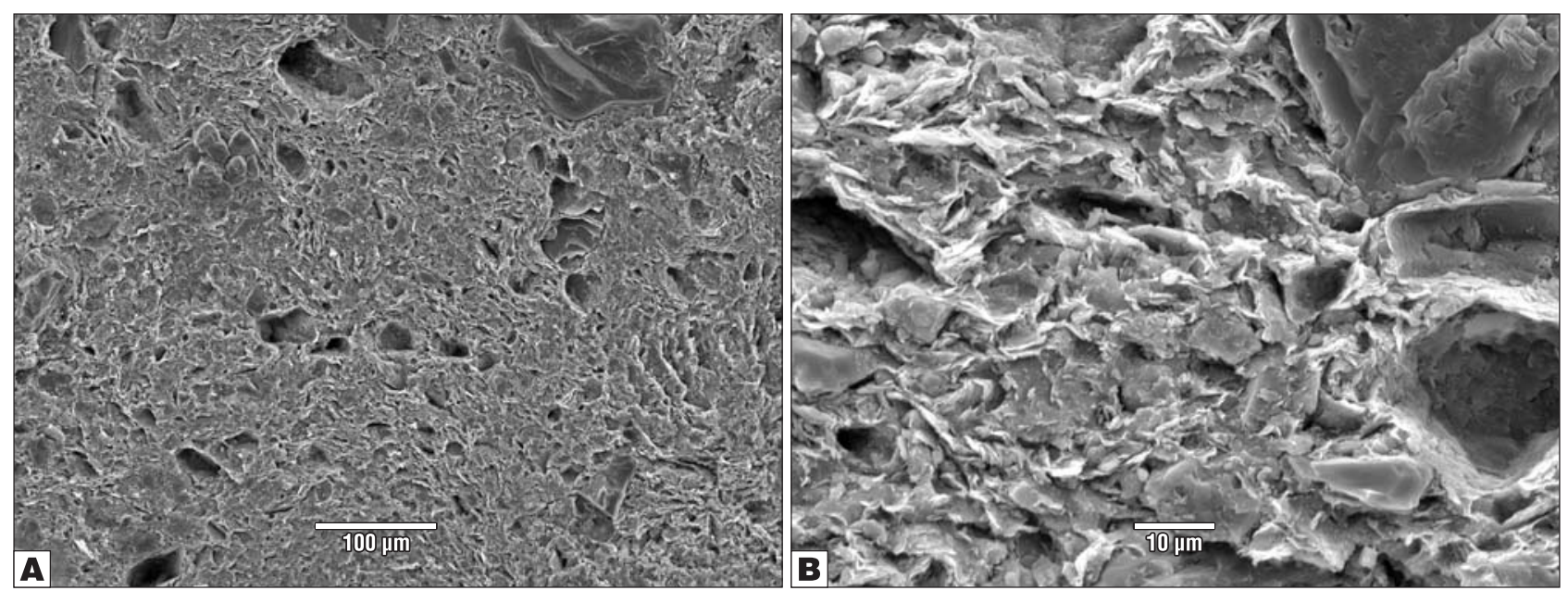

Ryc. 6. Mikrostruktura matrycowa pasty gruntowej przygotowanej z gliny lodowcowej po przeprowadzeniu badania CRL. Prędkość obciążania: $\mathbf{A}-100 \mathrm{kPa} / \mathrm{h} ; \mathbf{B}-25 \mathrm{kPa} / \mathrm{h}$

Fig. 6. Matrix microstructure of soil paste prepared from glacial till after CRL test. Loading velocity: A $-100 \mathrm{kPa} / \mathrm{h} ; \mathbf{B}-25 \mathrm{kPa} / \mathrm{h}$ 
Tab. 3. Miarodajne wartości parametrów konsolidacji otrzymane w trakcie badań CRL

Table 3. Reliable values of consolidation parameters obtained during CRL tests

\begin{tabular}{|c|c|c|c|c|}
\hline $\begin{array}{l}\text { Rodzaj próbki } \\
\text { Type of sample }\end{array}$ & $\begin{array}{l}\text { Symbol } \\
\text { Symbol }\end{array}$ & $\begin{array}{c}\text { Prędkość obciążania } \\
\text { Loading velocity } \\
\Delta \sigma / \Delta t[\mathrm{kPa} / \mathrm{h}]\end{array}$ & $\begin{array}{c}\text { Wspólczynnik konsolidacji } \\
\text { Coefficient of consolidation } \\
\qquad c_{v}\left[\mathrm{~m}^{2} / \mathrm{s}\right]\end{array}$ & $\begin{array}{c}\text { Wspólczynnik filtracji } \\
\text { Coefficient of permeability } \\
k[\mathrm{~m} / \mathrm{s}]\end{array}$ \\
\hline $\begin{array}{l}\text { Próbka nienasączana o zachowanej naturalnej } \\
\text { strukturze i naturalnej wilgotności } \\
\text { Unsaturated sample with natural structure } \\
\text { and natural water content }\end{array}$ & $\mathrm{N}-50$ & 50 & $6,2 \times 10^{-9}-8,1 \times 10^{-9}$ & $2,6 \times 10^{-12}-1,5 \times 10^{-11}$ \\
\hline \multirow{2}{*}{$\begin{array}{l}\text { Próbka o nienaruszonej strukturze nasączana } \\
\text { przy użyciu systemu back pressure } \\
\text { Undisturbed sample saturated with a back } \\
\text { pressure system }\end{array}$} & S-50 & 50 & $2,5 \times 10^{-9}-4,0 \times 10^{-9}$ & $1,1 \times 10^{-12}-8,4 \times 10^{-12}$ \\
\hline & S-100 & 100 & $5,1 \times 10^{-9}-6,3 \times 10^{-9}$ & $3,1 \times 10^{-12}-2,3 \times 10^{-11}$ \\
\hline \multirow{4}{*}{$\begin{array}{l}\text { Pasta gruntowa } \\
\text { Soil paste }\end{array}$} & $\mathrm{P}-12,5$ & 12,5 & $7,8 \times 10^{-9}-1,1 \times 10^{-8}$ & $3,4 \times 10^{-12}-5,3 \times 10^{-11}$ \\
\hline & $\mathrm{P}-25$ & 25 & $7,6 \times 10^{-9}-1,1 \times 10^{-8}$ & $3,7 \times 10^{-12}-2,6 \times 10^{-11}$ \\
\hline & $\mathrm{P}-50$ & 50 & $1,0 \times 10^{-8}-1,2 \times 10^{-8}$ & $4,6 \times 10^{-12}-1,9 \times 10^{-11}$ \\
\hline & P-100 & 100 & $7,2 \times 10^{-9}-9,7 \times 10^{-9}$ & $4,9 \times 10^{-12}-7,0 \times 10^{-12}$ \\
\hline
\end{tabular}

trójfazowego ośrodka gruntowego na stały wzrost obciążenia jest wyrażana przede wszystkim poprzez zmiany ciśnienia porowego oraz struktury gruntu.

W rozwiązaniach modelowych wyprowadzonych $\mathrm{z}$ teorii konsolidacji Terzaghiego (Dobak, 1999, 2008) wyróżnia się początkową fazę nieustaloną (Vu Cao Minh, 1977) $\mathrm{z}$ intensywnym wzrostem ciśnienia porowego oraz fazę ustaloną, w której jest spodziewana jego stabilizacja. Początkowy wzrost wartości $u_{b}$, występujący w nieustalonej fazie badania, wynika ze stopniowanej kumulacji efektów wzrastającego obciążenia. Natomiast stabilizacja wartości $u_{b} \mathrm{~W}$ przebiegu badania konsolidometrycznego wskazuje na osiagnnięcie równowagi między kolejnymi nieskończenie małymi przyrostami obciążenia $(\Delta \sigma)$ a rozpraszaniem ciśnienia porowego. Wymaga to jednak stałej wartości stosunku $H^{2} / c_{v}=\left(H^{2} \cdot \gamma_{w}\right) /\left(k \cdot M_{0}\right)$ w przebiegu badania, co przy zróżnicowaniu nasycenia gruntu i sukcesywnym zmniejszaniu się przestrzeni porowej może nie być spełnione. Uwarunkowania te trzeba uwzględniać $\mathrm{w}$ interpretowaniu charakterystyk doświadczalnych. Zależność $\sigma-u_{b} \mathrm{~W}$ glinach lodowcowych o nienaruszonej strukturze (ryc. 1A) ilustruje wpływ różnych przyjmowanych opcjonalnie warunków badania zarówno w gruntach o naturalnej wilgotności $(\mathrm{N})$, jak i próbek poddanych uprzedniemu nasyceniu $(\mathrm{S})$.

W gruntach o naturalnej strukturze nasycanie zaaplikowane techniką back pressure $=460 \mathrm{kPa}$ jest odzwierciedlone na wykresie odpowiednio przesuniętą początkową wartością naprężenia całkowitego (ryc. 1A). Pełna saturacja gruntu powoduje, że ciśnienie porowe osiąga znaczne wartości, a w przebiegu dalszego obciążania CRL wzrasta w sposób zbliżony do modelowego. Tendencja do jego stabilizacji jest uzależniona od prędkości obciążania. W przypadku zastosowania prędkości obciążania $50 \mathrm{kPa} / \mathrm{h}$ stabilizacja jest czytelna, natomiast - $100 \mathrm{kPa} / \mathrm{h}$ i większej obserwuje się osiaganie nie tylko wyższych wartości ciśnienia porowego $\mathrm{w}$ fazie intensywnego wzrostu, ale także brak pełnej stabilizacji $u_{b}$. Może to być spowodowane m.in. na skutek dławienia przepływu (Dobak, 1999), pojawiającego się pod wpływem wysokiego ciśnienia porowego. Zróżnicowane charakterystyki wzrostu $u_{b}=f(\sigma)$ w gruntach o naturalnej strukturze i wilgotności można natomiast wiązać z lokalną zmiennością w gruncie zwałowym nasycenia przestrzeni porowej.
W badaniach past gruntowych zależność $u_{b}-\sigma$ wykazuje pewną odrębność w stosunku do obserwowanych zachowań gruntów o naturalnej strukturze. Początkowy, intensywny wzrost ciśnienia porowego kończy się osiągnięciem $u_{\text {bmax }}$, którego wartość jest zazwyczaj, zgodnie z modelem teoretycznym, proporcjonalna do zaaplikowanej prędkości obciążania. Następnie jednak obserwuje się, odmiennie niż w teorii oraz $\mathrm{w}$ badaniach próbek o naturalnej strukturze, niewielki spadek ciśnienia porowego $\left(u_{b}\right)$. $\mathrm{W}$ badaniach prowadzonych $\mathrm{z}$ zastosowaniem mniejszej prędkości obciążania, w których uzyskiwano także mniejsze maksymalne ciśnienia porowe, stabilizacja $u_{b}$ następowała później na nieco obniżonym poziomie, co można wiązać z modelową fazą ustaloną badania CL. Na skutek większych prędkości obciążania i wynikających z nich wyższych wartości $u_{b \max }$ znaczniejsze obniżanie ciśnienia porowego następuje później (ryc. 1B).

Przedstawione efekty mogą być następstwem mniejszych więzi strukturalnych szkieletu gruntowego w pastach, które w warunkach in situ długo kształtują się w następstwie procesów postsedymentacyjnych (cementacja, prekonsolidacja). Pod wpływem wyższego ciśnienia porowego układ strukturalny może podlegać modyfikacjom w kierunku powstawania uprzywilejowanych stref lepszego odpływu. Powoduje to zmniejszenie nadwyżki ciśnienia porowego. Później, w warunkach stale rosnącego obciążenia całkowitego, strefy te są sukcesywnie zaciskane, co stwarza nowy stan strukturalny, w którym rozpraszanie ciśnienia porowego jest ustabilizowane.

Z uzyskanych danych doświadczalnych wynika istotne zróżnicowanie uwarunkowań strukturalnych gruntów skonsolidowanych w przeszłości geologicznej oraz past o znacząco mniejszych więziach, co skutkuje odrębnym typem zachowań konsolidacyjnych. Dokumentuje to istotną rolę aspektów strukturalnych w przebiegu konsolidacji w warunkach stale rosnącego obciążenia. Uzyskane zachowania glin zlodowacenia odry stanowią rozwinięcie efektów opisywanych w badaniach gruntów o innej pozycji litogenetycznej (Dobak, Kowalczyk, 2008; Kowalczyk i in., 2013; Dobak i in., 2015; Stajszczak, 2018, 2019).

Jednym z kryteriów miarodajności uzyskiwanych wyników jest ocena charakterystyk bezwymiarowego parametru ciśnienia wody w porach $C_{C L}$. Przyjmuje się, że w modelowym przebiegu konsolidacji CRL początkowa 
wartość parametru $C_{C L}$ powinna wynosić 1 . Wraz z postępem konsolidacji CL i odpływem wód porowych spodziewane wartości $C_{C L}$ sukcesywnie maleją, co wskazuje na rosnący udział szkieletu gruntowego w przenoszeniu stale wzrastającego obciążenia. W badaniach CRL poniżej wartości $C_{C L}=0,24$ proces teoretycznie wchodzi w fazę ustaloną - optymalną dla ocen współczynników $c_{v}$ i $k$.

Modelowy przebieg zmian wartości parametru $C_{C L}$ w funkcji stale wzrastającego obciążenia często nie jest uzyskiwany w trakcie prac doświadczalnych (m.in. Dobak i in., 2015; Stajszczak, 2018, 2019). Obserwowane rozbieżności mogą być tłumaczone niepełnym nasyceniem porów gruntu wodą na początkowym etapie badania oraz znaczącym w próbkach o nienaruszonej strukturze, a także udziałem silnych wiązań w szkielecie gruntowym, przejmujących zadawane obciążenia. Ilustrują to wykresy parametru ciśnienia wody w porach (ryc. 2A). Próbki NNS glin lodowcowych, poddane przed rozpoczęciem badania CRL procesowi saturacji, przyjmują wartości $C_{C L \max }$ ok. 1,7-2,5 razy wyższe od danych uzyskiwanych w toku badań próbek o zachowanej naturalnej wilgotności (ryc. 2A). Znaczniejszy udział fazy ciekłej w przenoszeniu stale wzrastającego obciążenia po nasączeniu badanych glin lodowcowych metodą back pressure sprawia, że wykresy $C_{C L}-\sigma$ przez cały czas badania były na etapie fazy nieustalonej z dużym udziałem wody w przenoszeniu obciążenia.

Analizując zmiany parametru ciśnienia wody w porach $\left(C_{C L}\right)$ w trakcie badań konsolidometrycznych próbek o nienaruszonej strukturze i naturalnej wilgotności można zaobserwować różne zachowania gruntów, zależne przypuszczalnie od początkowego nasycenia porów wodą oraz istniejących więzi strukturalnych. W przypadku badania próbki $\mathrm{N}-50 \mathrm{kPa} / \mathrm{h}$ mobilizacja ciśnienia porowego, a tym samym wzrost $C_{C L}$ następowały wolno (ryc. 2A), osiagając maksimum o wartości 0,5 , po czym dopiero następował powolny spadek. Takie zachowania świadczą o zmiennych w czasie obciążania relacjach ciśnienia wody i naprężenia przenoszonego przez szkielet, co zapewne jest warunkowane mikrostrukturą gruntu zwałowego, wykształconą w złożonych, długotrwałych procesach postsedymentacyjnych. W badaniu $\mathrm{N}-100 \mathrm{kPa} / \mathrm{h}$ odnotowano natomiast znacząco mniejszy udział ciśnienia porowego w przenoszeniu rosnących obciążeń, ale wartości $C_{C L}$ po początkowych zaburzeniach wykazywały obniżanie, a potem stabilizację. Obserwowane efekty mogą wynikać z różnego, losowego stanu cementacji na stykach cząstek i ziaren szkieletu gruntowego, chaotycznego układu strukturalnego glin lodowcowych oraz niejednorodności w stopniu nasycenia porów wodą. W warunkach stale wzrastającego obciążenia w pierwszej kolejności zostają zamknięte pory wypełnione powietrzem, co w przypadku ośrodka trójfazowego opóźnia także proces mobilizacji ciśnienia porowego.

Natomiast podczas badań CRL próbek past gruntowych uzyskano charakterystyki parametru $C_{C L}$ odpowiadające $\mathrm{z}$ dobrym przybliżeniem modelowi teoretycznemu (ryc. 2B). Zgodność zachowań past gruntowych z rozwiązaniami modelowymi wynika $\mathrm{z}$ pełnego nasycenia porów gruntu fazą ciekłą $(\mathrm{Sr}=1)$ oraz quasi-izotropowości szkieletu gruntowego. W pastach gruntowych czytelnie zaznacza się wpływ prędkości obciążania na uzyskiwane wartości $C_{C L}$. W przeprowadzonych badaniach przy prędkościach od $12,5 \mathrm{kPa} / \mathrm{h}$ do $50 \mathrm{kPa} / \mathrm{h}$ szybkie zmniejszanie $C_{C L}$ skutkowało osiaganiem fazy ustalonej. Jedynie $\mathrm{w}$ badaniu próbki $\mathrm{P}-100 \mathrm{kPa} / \mathrm{h}$ generowanie wysokich wartości ciśnienia porowego spowodowało zmianę modelowego kształtu krzywej $C_{C L}$, co zapewne mogło być spowodowane znaczącym dławieniem przepływu wody (Dobak, 1999) w przestrzeni porowej (ryc. 2B).

Zmiany właściwości filtracyjno-konsolidacyjnych badanych glin lodowcowych i past w warunkach rosnącego obciążenia są syntetycznie charakteryzowane przez współczynniki: konsolidacji oraz filtracji. Zależność $c_{v}-\sigma$ (ryc. 3A-B) stosunkowo najlepiej odwzorowuje funkcja potęgowa o ujemnym wykładniku. Wartości $c_{v}$ odpowiadające początkowemu etapowi obciążania są w sensie fizycznym przeważnie znacząco zawyżone i niemiarodajne. Wraz ze wzrostem ciśnienia porowego współczynnik konsolidacji $c_{v}$ wykazuje trend stabilizacyjny w postaci odcinka quasi-prostoliniowego. Jego niewielkie nachylenie do osi $\sigma$ ilustruje sukcesywne utrudnienia filtracji, wynikające ze zmniejszania objętości przestrzeni porowej oraz utrudnień przepływu na skutek wysokiego ciśnienia porowego (Dobak i in., 2015; Stajszczak, 2018).

W badaniach próbek NNS, które zostały poddane procedurze saturacji, wartości $c_{v}$ oraz $k$ są od połowy do jednego rzędu mniejsze od oznaczonych dla próbek NNS o wilgotności naturalnej. Obserwowane trendy można wytłumaczyć wpływem całkowitego nasycenia przestrzeni porowej gruntu spoistego. Niepełne nasycenie porów gruntu fazą ciekłą w warunkach stale wzrastającego obciążenia zazwyczaj skutkuje mniejszymi wartościami $u_{b}$. Fakt ten w sposób bezpośredni prowadzi do zawyżenia obliczanych wartości $c_{v}$ oraz $k$ gruntu nienasyconego.

Pozbawienie naturalnych więzi strukturalnych glin, z których sporządzano pasty gruntowe, oraz całkowite wypełnienie ich porów wodą powoduje, że przebieg konsolidacji CL past gruntowych jest bardziej zbliżony do modelu teoretycznego. Fakt ten sprawia, że uzyskiwane w zaawansowanych etapach badania CRL wartości $c_{v}$ oraz $k$ past gruntowych odpowiadają fazie ustalonej konsolidacji CL $\left(C_{C L}<0,24\right)$. Natomiast $\mathrm{w}$ analizowanych badaniach próbek NNS nie osiagano fazy ustalonej konsolidacji CL - w większości przypadków $C_{C L}$ było większe od 0,24 (ryc. 2A). Wymagało to korygowania wartości $c_{v}$ oraz $k$ z zastosowaniem w całym zakresie badania propozycji Janbu i in. (1981; patrz tab. 1).

Obserwowane trendy zmian parametrów filtracyjnokonsolidacyjnych w toku badań CRL znajdują odzwierciedlenie także w charakterystykach obrazów mikrostrukturalnych, interpretowanych ilościowo $\mathrm{z}$ zastosowaniem programu STIMAN (tab. 4).

Analiza wartości parametrów przestrzeni porowej próbek o nienaruszonej strukturze (NNS) oraz past gruntowych $(P)$ wskazuje, że na ich zmiany wpływają przede wszystkim ciśnienia porowe generowane w trakcie badań CRL oraz odkształcenia warunkowane przebudową układu cząstek szkieletu. Potwierdzają to wyniki badań CRL próbki NNS $(\Delta \sigma / \Delta$ t $50 \mathrm{kPa} / \mathrm{h})$ gliny lodowcowej zarówno nie poddanej $(\mathrm{N})$, jak i poddanej (S) procesowi saturacji (tab. 4). Wzrost udziału fazy ciekłej w przenoszeniu naprężeń całkowitych po przeprowadzeniu procedury nasączania będzie prowadzić do rejestrowania w chwili zakończenia badania CRL wyższej wartości ciśnienia porowego oraz mniejszego odkształcenia osiowego niż w badaniach próbek nienasycanych metodą back pressure (tab. 3 ). Mniejsze końcowe odkształcenia gruntu spoistego wynikaja 


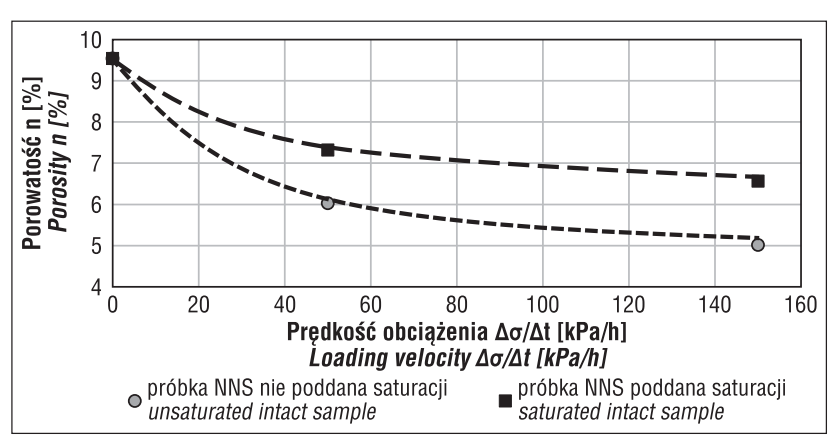

Ryc. 7. Wpływ prędkości obciążania na porowatość glin lodowcowych z rejonu Fortu Służew w Warszawie, oznaczoną z zastosowaniem programu STIMAN

Fig. 7. Influence of loading velocity on porosity values of glacial tills from the area of Fort Służew in Warsaw, obtained by STIMAN software

z większego udziału przestrzeni porowej w objętości próbki obciążanej, co wiąże się z wysokimi wartościami ciśnienia porowego w trakcie badania. Prawidłowości te w przeprowadzonych analizach ilościowych są wyrażone m.in. wartościami parametrów morfometrycznych mikrostruktury, określanych za pomocą programu STIMAN (tab. 4, ryc. 7). Warto jednak podkreślić, że zindywidualizowany w każdej próbce układ strukturalny i udziały faz mogą powodować odstępstwa od obserwowanych trendów.
W przypadku past gruntowych udokumentowane zmiany parametrów morfometrycznych mikrostruktury, analizowane na tle wartości ciśnień porowych rejestrowanych w chwili zakończenia badania CRL, nie w pełni koresponduja z przewidywaniami przedstawionymi w tym artykule (tab. 3). Najprawdopodobniej jest to spowodowane znaczną odkształcalnością przygotowanych past gruntowych, brakiem wiązań strukturalnych pomiędzy poszczególnymi elementami ich mikrostruktury, jak również istotnym udziałem frakcji piaskowej i pyłowej w składzie granulometrycznym badanych gruntów (tab. 2), co odbiega od raportowanych w literaturze charakterystyk gruntów bardzo spoistych, zawierających ponad 30\% frakcji iłowej (Kowalczyk, 2007; Stajszczak, 2019).

\section{WNIOSKI}

1) Filtracyjno-konsolidacyjne właściwości glin zlodowacenia odry określane w warunkach stale wzrastającego obciążenia (CRL) zależą od stopnia nasycenia porów gruntu fazą ciekłą, zmian ciśnienia porowego, uwarunkowanych stosowanymi prędkościami obciążania, oraz cech mikrostrukturalnych gruntu. Niepełne nasycenie porów fazą ciekłą zwiększa rolę szkieletu gruntowego w przenoszeniu stale wzrastającego obciążenia, przez co uzyskiwane w toku badania CL wartości $c_{v}$ oraz $k$ glin lodowcowych

Tab. 4. Wyniki ilościowej analizy mikrostruktury glin zlodowacenia odry

Table 4. Results of quantitative microstructural analysis of Odranian tills

\begin{tabular}{|c|c|c|c|c|c|c|c|c|}
\hline \multirow{2}{*}{$\begin{array}{l}\text { Parametr } \\
\text { Parameter }\end{array}$} & \multicolumn{5}{|c|}{$\begin{array}{l}\text { Pasta gruntowa } \\
\text { Soil paste }\end{array}$} & \multicolumn{2}{|c|}{$\begin{array}{l}\text { Próbka NNS } \\
\text { Intact sample }\end{array}$} & \multirow{2}{*}{$\begin{array}{c}\begin{array}{c}\text { Nasączana } \\
\text { próbka NNS } \\
\text { Saturated } \\
\text { intact sample }\end{array} \\
\mathrm{S}-\mathbf{5 0} \\
\mathrm{kPa} / \mathrm{h}\end{array}$} \\
\hline & $\mathbf{R}$ & $\begin{array}{l}\mathrm{R}-12,5 \\
\mathrm{kPa} / \mathrm{h}\end{array}$ & $\begin{array}{l}\mathrm{R}-25 \\
\mathrm{kPa} / \mathrm{h}\end{array}$ & $\begin{array}{l}\mathrm{R}-\mathbf{5 0} \\
\mathrm{kPa} / \mathrm{h}\end{array}$ & $\begin{array}{c}\mathrm{R}-100 \\
\mathrm{kP} / \mathrm{h}\end{array}$ & $\mathbf{N}$ & $\begin{array}{c}\mathrm{N}-\mathbf{5 0} \\
\mathrm{kP} / \mathrm{h}\end{array}$ & \\
\hline $\begin{array}{l}\text { Prędkość obciążenia }[\mathrm{kPa} / \mathrm{h}] \\
\text { Loading velocity }[\mathrm{kPa} / \mathrm{h}]\end{array}$ & p.o. & 12,5 & 25 & 50 & 100 & p.o. & 50 & 50 \\
\hline $\begin{array}{l}\text { Porowatość obliczona } \\
\text { w programie STIMAN [\%] } \\
\text { Porosity calculated in STIMAN [\%] }\end{array}$ & 17,4 & 8,6 & 3,9 & 5,4 & 4,4 & 9,5 & 6,0 & 7,3 \\
\hline $\begin{array}{l}\text { Porowatość obliczona w trakcie } \\
\text { badań laboratoryjnych } n[\%] \\
\text { Porosity calculated during } \\
\text { laboratory tests } n[\%]\end{array}$ & 50,0 & 31,0 & 30,0 & 31,0 & 31,0 & 33,0 & 25,0 & - \\
\hline $\begin{array}{l}\text { Średnia średnica porów } D_{a v}[\mathrm{um}] \\
\text { Average pore diameter } \mathrm{D}_{\mathrm{av}}[\mathrm{um}]\end{array}$ & 2,24 & 1,21 & 1,17 & 1,55 & 1,16 & 1,24 & 1,36 & 1,71 \\
\hline $\begin{array}{l}\text { Całkowita powierzchnia porów } S_{t} \cdot 10^{3}\left[\mathrm{um}^{2}\right] \\
\text { Total pore area } S_{t} \cdot 10^{3}\left[\mathrm{um}^{2}\right]\end{array}$ & 402 & 200 & 93 & 130 & 105 & 225 & 143 & 59 \\
\hline $\begin{array}{l}\text { Średnia powierzchnia porów } S_{a v}\left[\mathrm{um}^{2}\right] \\
\text { Average pore area } \mathrm{S}_{\mathrm{av}}\left[\mathrm{um}^{2}\right]\end{array}$ & 12,9 & 3,9 & 3,3 & 6,2 & 3,3 & 4,8 & 4,9 & 5,5 \\
\hline $\begin{array}{l}\text { Całkowity obwód porów } P_{t} \cdot 10^{3}[\mathrm{um}] \\
\text { Total pore perimeter } P_{t} \cdot 10^{3}[\mathrm{um}]\end{array}$ & 571 & 522 & 253 & 252 & 276 & 475 & 324 & 156 \\
\hline $\begin{array}{l}\text { Średni obwód porów } P_{a v} \cdot 10^{3}[\mathrm{um}] \\
\text { Average pore perimeter } P_{a v} \cdot 10^{3}[\mathrm{um}]\end{array}$ & 18 & 10 & 9 & 12 & 9 & 10 & 11 & 14 \\
\hline $\begin{array}{l}\text { Średni współczynnik formy porów } K_{f a v}[-] \\
\text { Average form index of pores } K_{f a v}[-]\end{array}$ & 0,56 & 0,51 & 0,51 & 0,54 & 0,48 & 0,49 & 0,46 & 0,46 \\
\hline $\begin{array}{l}\text { Wskaźnik anizotropii mikrostruktury } K_{\alpha}[\%] \\
\text { Microstructure anisotropy index } K_{\alpha}[\%]\end{array}$ & 21,8 & 13,9 & 33,9 & 31,5 & 29,1 & 14,6 & 30,0 & - \\
\hline $\begin{array}{l}\text { Ciśnienie porowe } u_{b}[\mathrm{kPa}] \\
\text { Pore pressure } u_{b}[\mathrm{kPa}]\end{array}$ & - & 52 & 103 & 160 & 344 & - & 536 & 652 \\
\hline $\begin{array}{l}\text { Odkształcenie osiowe } \varepsilon[\%] \\
\text { Axial strain } \varepsilon[\%]\end{array}$ & - & 37,3 & 37,1 & 38,7 & 38,5 & - & 10,9 & 8,6 \\
\hline
\end{tabular}

Objaśnienia / Explanations: p.o. - przed obciążeniem / before loading 
o naturalnej wilgotności są od 0,5 do 1 rzędu wielkości większe aniżeli w próbkach, które poddano procedurze saturacji. Fakt ten wskazuje, że wartości współczynnika konsolidacji $\left(c_{v}\right)$ oraz filtracji $(k)$, uzyskiwane w trakcie badań CRL gruntów nienasyconych, trzeba oceniać jako zawyżone. Skutkuje to szybszą stabilizacją osiadań, co może być ilościowo porównywane przez analizowanie wyników badań gruntów nienasyconych i poddanych saturacji. Jednocześnie tempo przykładania obciążenia zarówno w laboratorium, jak i w terenie skutkuje zmianami czasu konsolidacji i powinno być uwzględniane podczas programowania prędkości obciążania w badaniach laboratoryjnych.

2) Wartości współczynnika filtracji $k$ oraz konsolidacji $c_{v}$, oznaczone $\mathrm{w}$ toku badań próbek NNS oraz past gruntowych przygotowanych z glin zlodowacenia odry, mają podobny rząd wielkości i korespondują z danymi uzyskiwanymi z zastosowaniem innych metod (Bakkowska i in., 2016). W przeprowadzonym programie badań CRL pozbawienie materiału gruntowego naturalnej struktury poprzez przygotowanie past znacząco wpłynęło na przebieg konsolidacji CL. Kluczowe dla ocen konsolidacji typu CL zależności $C_{C L}-\sigma$ są w przypadku badań past gruntowych bliższe rozwiązaniom teoretycznym aniżeli przebieg badań próbek NNS nienasączanych oraz nasączanych metodą back pressure. Obserwowane rozbieżności w reakcjach gruntów o naturalnej strukturze wynikają ze znacznego udziału szkieletu gruntowego w przenoszeniu stale wzrastającego obciążenia, co w bezpośredni sposób może wynikać z cementacyjnych więzi w szkielecie, wzmocnionych prekonsolidacją gruntu.

3) Gliny zlodowacenia odry, zarówno przed obciążeniem $\mathrm{w}$ konsolidometrze, jak i po nim, zachowują mikrostrukturę matrycową. Po zakończeniu badania CL w glinach lodowcowych poddanych saturacji stwierdzono porowatość większą o ok. $25 \%$ aniżeli w badanych próbkach o wilgotności naturalnej. Obserwowane w przebiegu badań CRL zmiany właściwości filtracyjno-konsolidacyjnych zaznaczają się przede wszystkim na skutek wysokiego udziału fazy ciekłej w przenoszeniu zadawanych obciążeń, co można odnotować w przypadku zastosowania procedury nasączania metodą back pressure gruntów NNS oraz wykonanych z nich past.

4) W następstwie stałego przyrostu obciążenia odnotowano pewne przeorientowanie elementów strukturalnych szkieletu gruntowego glin lodowcowych, co w przeprowadzonych analizach ilościowych zostało wyrażone 0,5-1,0-krotnym wzrostem wartości współczynnika formy porów $K_{\alpha}$ po obciążeniu. Efekty te należy wiązać ze wzrostem upakowania szkieletu i zmniejszeniem porowatości gruntu w warunkach jednoosiowego odkształcenia próbek.

\section{LITERATURA}

ABOSHI H., YOSHIKUMI H., MAURYAMA S. 1970 - Constan Loading Rate Consolidation Test. Soils and Foundations, 10 (1): 43-56. BAZKOWSKA A., DOBAK P., GAWRIUCZENKOW I., KIEŁBASIŃSKI K., SZCZEPANSKI T., TRZCINSKI J., WOJCIK E., ZAWRZYKRAJ P. 2016 - Stress-strain behaviour analysis of Middle Polish glacial tills from Warsaw (Poland) based on the interpretation of advanced field and laboratory tests. Acta Geol. Pol., 66 (3), 561-585.

DOBAK P. 1999 - Rola czynnika filtracyjnego w badaniach jednoosiowej konsolidacji gruntów. Wyd. IGSMiE PAN, Kraków.
DOBAK P. 2003 - Loading velocity in consolidation analysis. Geol. Quart., 47 (1): 13-20.

DOBAK P. 2008 - Evaluation of consolidation parameters in CL tests; theoretical and practical aspects. Geol. Quart., 52 (4): 397-410.

DOBAK P., GASZYŃSKI J. 2015 - Evaluation of soil permeability from consolidation analysis based on Terzaghi's and Biot's theories. Geol. Quart., 59 (2): 373-381.

DOBAK P., KOWALCZYK S. 2008 - Consolidation parameters of Neogene green clays from Bełchatów - a study on CL test interpretation. Gelogija, 50: 20-25

DOBAK P., SZCZEPAŃSKI T., KOWALCZYK S. 2015 - Load velocity influence on changes of soil consolidation and permeability parameters in CL-type tests. Geol. Quart., 59 (2): 382-390.

DUNCAN J.M. 1993 - Limitations of Conventional Analysis of Consolidation Settlement. J. Geotech. Engineering, 119 (9): 1333-1359.

HEAD K.H. 1986 - Manual of Soil Laboratory Testing. Pentch Press, London.

JANBU N., TOKHEIM O., SENNESET K. 1981 - Consolidation tests with continuous loading. Procc. of $10^{\text {th }}$ International Conference on Soil Mechanics and Foundation Engineering (Stockholm), 4 (26): 645-654.

KACZYŃSKI R. 2017 - Warunki geologiczno-inżynierskie na obszarze Polski. Państw. Inst. Geol.-PIB.

KOŚCIÓWKO H., WYRWICKI R. 1996 - Metodyka badań kopalin ilastych. Państw. Inst. Geol.

KOWALCZYK S., SZCZEPAŃSKI T., DOBAK P. 2013 - Charakterystyka rozkładu ciśnienia porowego w badaniach konsolidacji past gruntowych z północnopolskich glin zwałowych. Budow. i Inżynieria Środ., 4 (2): $127-134$.

MYŚLIŃSKA E. 2001 - Laboratoryjne badania gruntów. Wyd. UW, Warszawa.

PAJAॄK R., DOBAK P. 2008 - Określenie parametrów filtracyjnych iłów krakowieckich z badań w konsolidometrze Rowe'a. Kwart. AGH Geologia, 34 (4): 677-689.

PN-86/B-02480 - Grunty budowlane. Określenia, symbole, podział i opis gruntów.

PN-88/B-04481 - Grunty budowlane. Badania laboratoryjne.

PN_EN ISO 14688-1 - Rozpoznanie i badania geotechniczne. Oznaczanie $\bar{i}$ klasyfikowanie gruntów. Część 1: Oznaczanie i opis.

PN EN ISO 14688-2 - Rozpoznanie i badania geotechniczne. Oznaczanie $\bar{i}$ klasyfikowanie gruntów. Część 2: Zasady klasyfikowania.

PN-EN ISO 17892-5 - Rozpoznanie i badania geotechniczne. Badania laboratoryjne gruntów. Część 5: Badanie edometryczne gruntów.

SERGEYEV J.M, GRABOWSKA-OLSZEWSKA B., OSIPOV V.I., SOKOLOV V.N., RAU E.I. 1980 - The classification of microstructures of clay soils. J. Microscopy, 120: 237-260.

SINHA U.N., BHARGAVA S.N. 1991 - Variation in differential pore water pressure and particle size at different constant rate of loading in an automated consolidation testing system. Geotech. Engineering, 22: $247-256$.

SOKOLOV V.N. 1990 - Engineering-geological classification of clay microstructures. Proc. $6^{\text {th }}$, Inter. IAEG Congress, 1: 753-760.

SOUMAYA B., KEMPFERT H.G. 2010 - Verformungsverhalten weicher Böden im spannungsgesteuerten Kompressionsversuch. Bautechnik, 87 (2): 73-80.

STAJSZCZAK P. 2018 - Filtracyjno-konsolidacyjne właściwości iłów mio-plioceńskich z rejonu Bud Mszczonowskich w warunkach stale wzrastającego obciążenia. Prz. Geol., 66: 558-568.

STAJSZCZAK P. 2019 - Wpływ zanieczyszczenia paliwami ropopochodnymi na zmiany parametrów filtracyjno-konsolidacyjnych i strukturalnych w gruntach spoistych. Arch. Wydz. Geol. UW - pr. doktorska.

SZCZEPAŃSKI T. 2007 - Przykłady zastosowań parametrów inherentnych w badaniach gruntów spoistych. Geologos, 11: 405-410.

TRZCIŃSKI J. 1995 - Qualitative and quantitative analysis of microstructures in Polishglacial tills with respect to their Age. Geol. Quart., 39 (3): 403-422.

VU CAO MINH 1977 - Nowa metoda badań konsolidacji gruntów. Arch. Hydrotech., 24 (2): 253-265.

ZAWRZYKRAJ P., RYDELEK P., BAKOWSKA A. 2017 - Geo-engineering properties of Eemian peats from Radzymin (central Poland) in the light of static cone penetration and dilatometer tests. Engineering Geol., 226: $290-300$

ZHANG P., LIU Z., SONG J. 2016 - Pore microstructure variation in gradient consolidation of Pearl River Delta saturated clay. Proceedings of the $20154^{\text {th }}$ International Conference on Sensors, Measurement and Intelligent Materials.

Praca wpłynęła do redakcji 7.05.2020 r

Akceptowano do druku 2.09.2020 r. 